\title{
Elemental Characterization of African Locust Beans (Parkia biglobosa) in Igbope, Oyo State of Nigeria
}

\author{
Caleb Ayoade Aborisade ${ }^{1,2}$, Latif M. Bakare ${ }^{3}$, Fatai Olabanji Balogun ${ }^{4}$ \\ ${ }^{1}$ Department of Physics and Engineering Physics, Obafemi Awolowo University \\ Ile-Ife Nigeria \\ Email: caborisade [AT] yahoo.com \\ ${ }^{2}$ Department of Physical Sciences, First Technical University \\ Ibadan, Nigeria \\ Email: caborisade [AT] yahoo.com \\ ${ }^{3}$ Center for Energy Research and Development, Obafemi Awolowo University \\ Ile-Ife, Nigeria \\ Email: mlatif [AT] cerd.gov.ng \\ ${ }^{4}$ Department of Earth Sciences, University of Oregon, \\ Oregon, USA \\ Email: fbalogun [AT] oregon.edu
}

\begin{abstract}
African locus beans (Parkia biglobosa) tree is a perennial legume tree that grows naturally in Africa and one of the trees the Forest Rangers enforced that farmers must preserve in their farmland because of its usefulness. Parkia biglobosa when fermented can be used to produce Iru and other useful products. This work employed the Particle Induced X-ray Emission (PIXE) in the determination of major, minor and trace element constituents of leaves, seeds, stem in Parkia biglobosa from Igbope, using a $2.5 \mathrm{MeV}$ proton ion beam analysis (IBA) facility. The samples contain nineteen (19) elements namely; $\mathrm{Na}, \mathrm{Mg}, \mathrm{Al}, \mathrm{Si}, \mathrm{P}, \mathrm{S}, \mathrm{Cl}, \mathrm{K}, \mathrm{Ca}, \mathrm{Ti}, \mathrm{Cr}, \mathrm{Mn}, \mathrm{Fe}, \mathrm{Cu}, \mathrm{Zn}, \mathrm{Br}, \mathrm{Sr}, \mathrm{Y}$ and $\mathrm{Ba}$. Calcium has

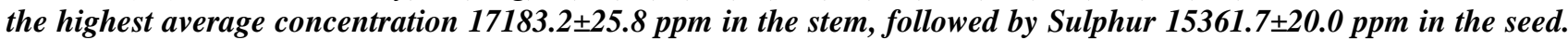
The seed that is locally fermented to produce Iru has a higher concentration of Fe $1266.8 \pm 12.3 \mathrm{ppm}$. The results showed that Parkia biglobosa analysed in this work consist of several micro, major and trace elements of importance to human health. The plant is also free of harmful elements that can be hazardous to human health when consumed or used as herbal medicine.
\end{abstract}

Keywords--- African locust bean, Parkia biglobosa, seed, leave, stem, elemental characterization

\section{INTRODUCTION}

African locust beans (Parkia biglobosa) tree is one of the naturally grown trees in Nigeria, it is perennial tree legume. It plays an important part in traditional agriculture, but has not entered commercial trade to any significant extent in Nigeria. In Igbope and its environs where the samples for this work were taken, it is one of the trees that farmers must preserve in their farm land (i.e. it must not be cut down or burned) and it grows naturally because the Forest Rangers will arrest and charge to court anybody that tamper with the tree because of the high value placed on the tree as a result of the usefulness of the products. The tree also improves soil fertility, its stem, seed, and leaves are used as traditional medicine. Parkia trees are found in Africa, South-East Asia and tropical South-America. In Malaysia and Indonesia, the whole pods, including seeds of Parkia biglobosa, are eaten raw or cooked as a vegetable known as petal. In West Africa, from Gambia to Cameroun including Nigeria, the beans of Parkia biglobosa, are widely fermented to the traditional dawadawa, while the yellow pericarp pulp is eaten as a fresh food, or as a supplement while taken pap and other foods. Traditionally, small quantities of dawadawa are used as a protein and fat-rich flavoursome ingredient of the traditional soups and stews eaten in West Africa both at individual's homes and food vendours.

The seed of Parkia biglobosa tree is called "Iyere" in Yoruba while the fermented seed is called "Iru". This Iru is one of the significant wellsprings of plant protein in Africa eating routine which is known as aged vegetable protein. Iru is expended in numerous African nations, particularly Nigeria. According to Teklehaimanot, (2004), the vital use of the 
populace of this tree is lessening and it remains semi-or undomesticated [1]. The scenario occurs in Nigeria. According to Olowokere et. al. (2018), the seed of the African locust bean yield more crude fat, crude protein, ash content, crude fibre, moisture content than Date palm seed but lower contents of carbohydrates. Also, the oil from the seed of the Parkia biglobosa which is yellowish brown in colour has higher acid, iodine, peroxide values, free fatty acid but less saponification value [2]. Parkia biglobosa when been fermented locally it can be softened to produce Sonru and Iru by the addition of Yanyanku and Ikpiru [3]. Femi-Ola et. al., (2008), established that the extraction of raw Parkia biglobosa can be used to kill termites, so also the aqueous and acetone extractions of Parkia biglobosa, the rate of killing of termites depends on the concentration of the extraction [4]. In the work of Omafuvbe et al. (2004) it was reported that boiling, soaking in water and dehulling of African locust bean (Parkia. biglobosa) led to the reduction of ash, crude fiber and mineral contents of the seeds. [5]. Gernmah et. al. (2007), determine the nutritional and anti-nutritional composition of the African locust bean (Parkia biglobosa), the work showed that the African locust bean fruit pulp is a very good source of food which can compete favourably with many cereals and legumes, it is also, a good source of macro and micro-nutrients, it yellow colour has high sugar content in acceptable and safe levels. [6]. It was established that the sugar level of fermented locust bean decrease significantly during the first 12 hours and the rate of reduction is sugar content decrease with time [7].

Parkia speciosa tree will contain several elemental and mineral compositions. The farmers at Igbope use fertilizers that contain some element such as potassium, calcium, nitrogen, etc, to augment the soil nutrients, which may lead to excesses of these element in the Parkia speciosa products. In Nigeria, apart from using Iru as soup supplement, nearly all parts of Parkia speciosa tree are used as traditional medicine to treat some ailments. When the tree grows old and die, the woods of the tree would be burned into ashes and the ashes are process further into local black soap. The black soap is used for bathing and for local medicine. This traditional medication was done without recon to elemental characterisation of Parkia biglobosa. This study is carried out to determine the elemental characterisation in the leaves, seeds and stem of the locust beans tree from Igbope, Oyo State of Nigeria using Particle Induced X-ray Emission (PIXE). It will also determine if the location contains the hidden beneficial or toxic elements. In addition, the results from this research will be more relevant if certain elements that are beneficial to human in the Parkia speciosa that were not detected by other researchers who used other methods are detected. The community will also be informed of the danger if the samples contain any harmful elements because the wood of the tree is used for cooking.

\section{MATERIAL AND METHODS}

The technique of using the Particle Induced X-ray Emission (PIXE) employed in the determination of major, minor and trace element constituents of leaves, seeds, steam in Parkia biglobosa from Igbope, using a $2.5 \mathrm{MeV}$ proton ion beam analysis (IBA) facility at the Center for Energy Research and Development (CERD), Obafemi Awolowo University, (OAU) Ile-Ife, has been fairly explained elsewhere by Aborisade et. al. (2020) [8]. However, it suffices to mention that the counting equipment make use of the computer code GUPIXWIN a versatile software package for fitting PIXE spectra from thin, thick, intermediate and layered specimens. GUPIXWIN extracts peak intensities which converts to concentrations via the $\mathrm{H}$-value standardisation method. It also, provides a non-linear least square fitting of the spectrum, together with subsequent conversion of the fitted X-ray peak intensities into elemental concentrations [9-11].

\section{Sample Collection}

Samples of Parkia biglobosa were collected from Igbope a town in Oyo State of Nigeria. Igbope is located in an area where majority food and fruits products were produced by farmers and marketers bought from the farm and sold to other states in the country. The samples collected were Parkia biglobosa leaves, seeds, and stem peal from ten (10) different locations and were packed into well labelled bags. Because of good humidity and proper soil topography in the location most of the plant can grow.

\section{Sample Preparation}

The sample of Parkia biglobosa leaves, seeds, and stem were wash thoroughly with distil water so as to remove superficial contamination and were allowed to dry at room temperature. The binding of the pellet was improved by grounding the dried samples in an agate mortar and mixed with $10 \%$ by weight of ultra-pure graphite powder prepared into thick pellets of $13 \mathrm{~mm}$ diameter. These grinded samples were taken to the accelerator room at CERD, Obafemi Awolowo University, Ile-Ife, for PIXE analysis.

\section{RESULTS AND DISCUSSION}

The values of the average of the concentration (ppm) of each element in Parkia biglobosa from the ten (10) locations are presented in table 1 for leaves, table 2 seeds and table 3 for stem. Table 4 show the average concentration (ppm) of each element in Parkia biglobosa from all the samples presented in table 4. 
Table 1: The Average Concentration (ppm) of Elements in Leaves

\begin{tabular}{|c|c|c|}
\hline $\begin{array}{l}\text { Atomic } \\
\text { number }(Z)\end{array}$ & Element & Concentration \\
\hline 11 & $\mathrm{Na}$ & $18.8 \pm 7.6$ \\
\hline 12 & $\mathrm{Mg}$ & $2473.6 \pm 19.8$ \\
\hline 13 & $\mathrm{Al}$ & $429.4 \pm 7.9$ \\
\hline 14 & $\mathrm{Si}$ & $3200.2 \pm 11.2$ \\
\hline 15 & $\mathrm{P}$ & $1019.4 \pm 11.1$ \\
\hline 16 & $S$ & $1130.0 \pm 8.5$ \\
\hline 17 & $\mathrm{Cl}$ & $740.3 \pm 6.7$ \\
\hline 19 & $\mathrm{~K}$ & $5228.4 \pm 12.5$ \\
\hline 20 & $\mathrm{Ca}$ & $11247.5 \pm 20.2$ \\
\hline 22 & $\mathrm{Ti}$ & $55.7 \pm 5.1$ \\
\hline 24 & $\mathrm{Cr}$ & $30.3 \pm 4.8$ \\
\hline 25 & $\mathrm{Mn}$ & $173.8 \pm 6.4$ \\
\hline 26 & $\mathrm{Fe}$ & $501.2 \pm 9.9$ \\
\hline 28 & $\mathrm{Ni}$ & ND \\
\hline 29 & $\mathrm{Cu}$ & $9.5 \pm 3.5$ \\
\hline 30 & $\mathrm{Zn}$ & $7.0 \pm 6.3$ \\
\hline 33 & As & ND \\
\hline 35 & $\mathrm{Br}$ & ND \\
\hline 37 & $\mathrm{Rb}$ & ND \\
\hline 38 & $\mathrm{Sr}$ & $134 \pm 45.7$ \\
\hline 39 & $\mathrm{Y}$ & ND \\
\hline 40 & $\mathrm{Zr}$ & ND \\
\hline 56 & $\mathrm{Ba}$ & $223.3 \pm 29.9$ \\
\hline 82 & $\mathrm{~Pb}$ & ND \\
\hline
\end{tabular}

Table 2: The Average Concentration (ppm) of Elements in Seed

\begin{tabular}{|c|c|c|}
\hline $\begin{array}{l}\text { Atomic } \\
\text { number }(\mathrm{Z})\end{array}$ & Element & Concentration \\
\hline 11 & $\mathrm{Na}$ & ND \\
\hline 12 & $\mathrm{Mg}$ & $3375.2 \pm 20.3$ \\
\hline 13 & $\mathrm{Al}$ & $228.9 \pm 7.3$ \\
\hline 14 & $\mathrm{Si}$ & $3041.1 \pm 10.6$ \\
\hline 15 & $\mathrm{P}$ & $3205.7 \pm 12.8$ \\
\hline 16 & $\mathrm{~S}$ & $15361.7 \pm 20.0$ \\
\hline 17 & $\mathrm{Cl}$ & $770.6 \pm 10.4$ \\
\hline 19 & $\mathrm{~K}$ & $13777.7 \pm 22.0$ \\
\hline 20 & $\mathrm{Ca}$ & $4446.2 \pm 22.7$ \\
\hline 22 & $\mathrm{Ti}$ & $17.1 \pm 4.3$ \\
\hline 24 & $\mathrm{Cr}$ & $40.6 \pm 4.3$ \\
\hline 25 & $\mathrm{Mn}$ & $54.6 \pm 4.3$ \\
\hline 26 & $\mathrm{Fe}$ & $1266.8 \pm 12.3$ \\
\hline 28 & $\mathrm{Ni}$ & ND \\
\hline 29 & $\mathrm{Cu}$ & $3.7 \pm 2.1$ \\
\hline 30 & $\mathrm{Zn}$ & $33.2 \pm 4.0$ \\
\hline 33 & As & ND \\
\hline 35 & $\mathrm{Br}$ & ND \\
\hline 37 & $\mathrm{Rb}$ & ND \\
\hline 38 & $\mathrm{Sr}$ & ND \\
\hline 39 & $\mathrm{Y}$ & ND \\
\hline 40 & $\mathrm{Zr}$ & ND \\
\hline 56 & $\mathrm{Ba}$ & $100.7 \pm 24.6$ \\
\hline 82 & $\mathrm{~Pb}$ & ND \\
\hline
\end{tabular}


Table 3: The Average Concentration (ppm) of Elements in Stem

\begin{tabular}{|c|c|c|}
\hline $\begin{array}{l}\text { Atomic } \\
\text { number }(Z)\end{array}$ & Element & Concentration \\
\hline 11 & $\mathrm{Na}$ & $27.3 \pm 7.8$ \\
\hline 12 & $\mathrm{Mg}$ & $2833.8 \pm 21.0$ \\
\hline 13 & $\mathrm{Al}$ & $495.8 \pm 8.4$ \\
\hline 14 & $\mathrm{Si}$ & $1184.7 \pm 8.8$ \\
\hline 15 & $\mathrm{P}$ & $767.3 \pm 10.4$ \\
\hline 16 & $\mathrm{~S}$ & $672.2 \pm 6.7$ \\
\hline 17 & $\mathrm{Cl}$ & $937.7 \pm 6.2$ \\
\hline 19 & $\mathrm{~K}$ & $6346.5 \pm 12.7$ \\
\hline 20 & $\mathrm{Ca}$ & $17183.2 \pm 25.8$ \\
\hline 22 & $\mathrm{Ti}$ & $37.9 \pm 6.6$ \\
\hline 24 & $\mathrm{Cr}$ & $35.4 \pm 5.9$ \\
\hline 25 & $\mathrm{Mn}$ & $129.0 \pm 7.5$ \\
\hline 26 & $\mathrm{Fe}$ & $331.7 \pm 10.6$ \\
\hline 28 & $\mathrm{Ni}$ & ND \\
\hline 29 & $\mathrm{Cu}$ & ND \\
\hline 30 & $\mathrm{Zn}$ & ND \\
\hline 33 & As & ND \\
\hline 35 & $\mathrm{Br}$ & $79.2 \pm 23.5$ \\
\hline 37 & $\mathrm{Rb}$ & ND \\
\hline 38 & $\mathrm{Sr}$ & $127.1 \pm 30.7$ \\
\hline 39 & $\mathrm{Y}$ & $74.1 \pm 25.8$ \\
\hline 40 & $\mathrm{Zr}$ & ND \\
\hline 56 & $\mathrm{Ba}$ & $513.6 \pm 35.0$ \\
\hline 82 & $\mathrm{~Pb}$ & ND \\
\hline
\end{tabular}

Table 4: The Average Concentration (ppm) of Elements in all sample analysed.

\begin{tabular}{|c|c|c|c|c|}
\hline \multirow{2}{*}{$\begin{array}{l}\text { Atomic } \\
\text { number }(Z)\end{array}$} & \multirow[t]{2}{*}{ Element } & \multicolumn{3}{|c|}{ Concentration } \\
\hline & & Stem & Seed & Leave \\
\hline 11 & $\mathrm{Na}$ & 27.3 & ND & 18.8 \\
\hline 12 & $\mathrm{Mg}$ & 2833.8 & 3375.2 & 2473.6 \\
\hline 13 & $\mathrm{Al}$ & 495.8 & 228.9 & 429.4 \\
\hline 14 & $\mathrm{Si}$ & 1184.7 & 3041.1 & 3200.2 \\
\hline 15 & $\mathrm{P}$ & 767.3 & 3205.7 & 1019.4 \\
\hline 16 & $\mathrm{~S}$ & 672.2 & 15361.7 & 1130.0 \\
\hline 17 & $\mathrm{Cl}$ & 937.7 & 770.6 & 740.3 \\
\hline 19 & $\mathrm{~K}$ & 6346.5 & 13777.7 & 5228.4 \\
\hline 20 & $\mathrm{Ca}$ & 17183.2 & 4446.2 & 11247.5 \\
\hline 22 & $\mathrm{Ti}$ & 37.9 & 17.1 & 55.7 \\
\hline 24 & $\mathrm{Cr}$ & 35.4 & 40.6 & 30.3 \\
\hline 25 & $\mathrm{Mn}$ & 129.0 & 54.6 & 173.8 \\
\hline 26 & $\mathrm{Fe}$ & 331.7 & 1266.8 & 501.2 \\
\hline 28 & $\mathrm{Ni}$ & ND & ND & ND \\
\hline 29 & $\mathrm{Cu}$ & ND & 3.7 & 9.5 \\
\hline 30 & $\mathrm{Zn}$ & ND & 33.2 & 7.0 \\
\hline 33 & As & ND & ND & ND \\
\hline 35 & $\mathrm{Br}$ & 79.2 & ND & ND \\
\hline 37 & $\mathrm{Rb}$ & ND & ND & ND \\
\hline 38 & $\mathrm{Sr}$ & 127.1 & ND & 134 \\
\hline 39 & $\mathrm{Y}$ & 74.1 & ND & ND \\
\hline 40 & $\mathrm{Zr}$ & ND & ND & ND \\
\hline 56 & $\mathrm{Ba}$ & 513.6 & 100.7 & 223.3 \\
\hline 82 & $\mathrm{~Pb}$ & ND & ND & ND \\
\hline
\end{tabular}




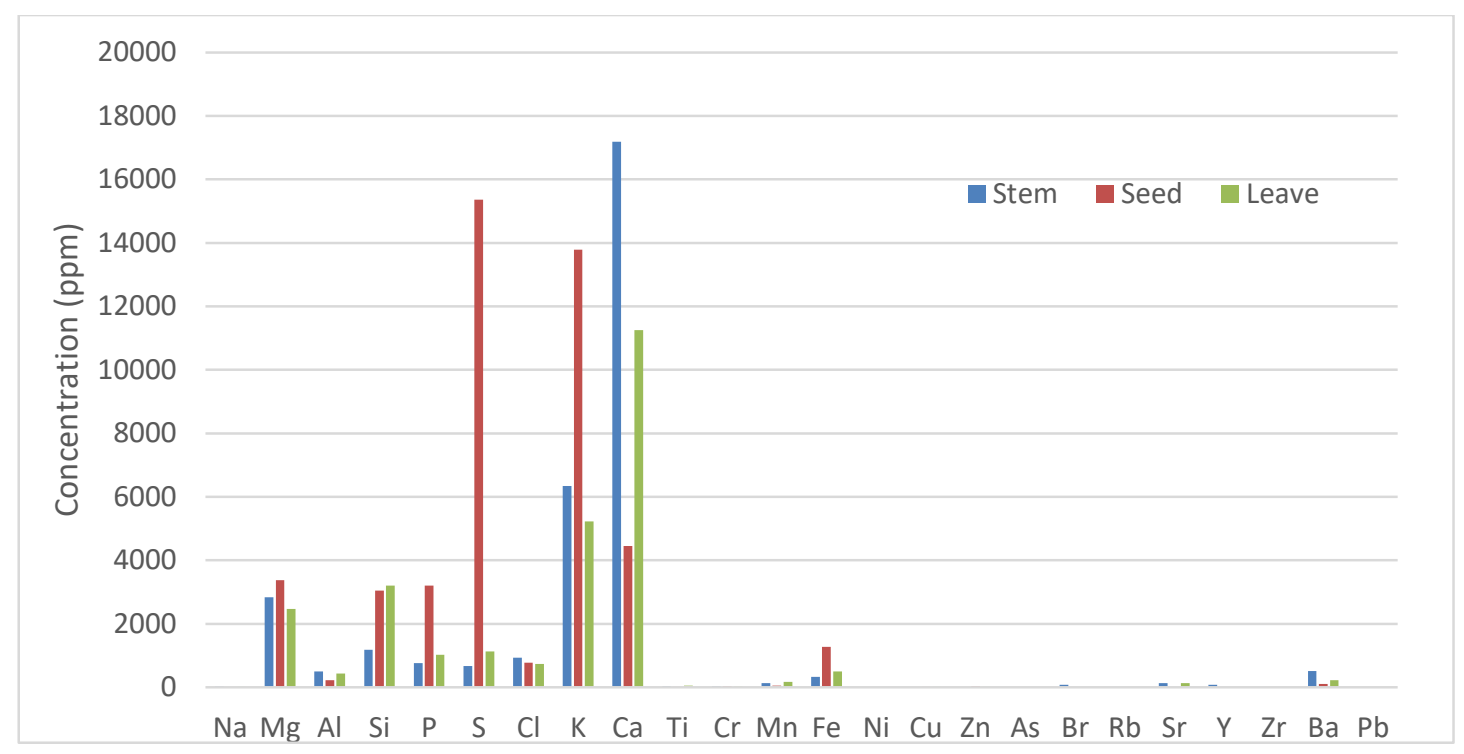

Figure 1: The Elemental Concentration (ppm) in all the Samples

The results showed that the Parkia biglobosa contains nineteen (19) elements namely; $\mathrm{Na}, \mathrm{Mg}, \mathrm{Al}, \mathrm{Si}, \mathrm{P}, \mathrm{S}, \mathrm{Cl}, \mathrm{K}, \mathrm{Ca}, \mathrm{Ti}$, $\mathrm{Cr}, \mathrm{Mn}, \mathrm{Fe}, \mathrm{Cu}, \mathrm{Zn}, \mathrm{Br}, \mathrm{Sr}, \mathrm{Y}$ and $\mathrm{Ba}$ as shown in table 3. Table 1, showed that the leave contains seventeen (17) elements, $\mathrm{Br}$ and $\mathrm{Y}$ are absent from the leave but present in stem of the plant. Table 2 showed that fifteen (15) elements were present in the seed, $\mathrm{Y}, \mathrm{Sr}, \mathrm{Br}$ and $\mathrm{Na}$ are absent in the seed. But $\mathrm{Zn}$ and $\mathrm{Cu}$ could be traced from the seed. From table 3 , seventeen (17) elements are present in the stem, but the traces of $\mathrm{Cu}$ and $\mathrm{Zn}$ that were present in leave and seed were absent in the stem. In all the samples analyzed $\mathrm{Ca}$, has the highest concentration of $17183.2 \pm 25.8 \mathrm{ppm}$ which was from the stem, followed by S, $15361.7 \pm 20.0 \mathrm{ppm}$ in the seed. Figure 1 shows that the seed contains the useful elements in the good proportion when compared with other part of the plant. The concentration of Al, Si and Fe in seed that is be fermented to make Iru is higher in this plant when compared with Moringa Oleifera [12].

Africa locust bean contains trace and major elements of importance to human health in good proportion. Calcium which has the highest concentration in this work is one of the macronutrients that all living organisms including humans being, because it is the most abundant mineral in the body, and it gives health and strong bone. The nerves and muscles in the heart need calcium for proper functioning, it also, protect against cancer, diabetes, high blood pressure and enables blood clotting. The calcium is also necessary for maintaining proper communication between the brain and other parts of the body. It plays a role in muscle movement and cardiovascular function [13]. According to the National Health and Nutrition Examination Survey (NHANES) the body of an adult human being requires nothing less than 4,700 mg of potassium, one of the seven macrominerals for its daily major processes [14]. In Nigeria, we consume less fruits and leaves than required. Though commercial supplements for potassium are available but obtaining any vitamin or mineral through diets that contain the required macro and micro elements is better, because it is not individual vitamins or minerals that make certain foods important for healthy living, but the combined efforts of a range of nutrients. This potassium is an electrolyte that neutralize the effects of sodium in human body. From the result of this work the concentration of Na, present in this plant is negligible when compared with K. Potassium also, helps to maintain consistent blood pressure and the balance of acids and bases in human body. The deficiency of potassium can trigger respiratory failure, which can lead to fatigue and constipation. Sulphur which has significantly high concentration in seeds in this work is the third most abundant mineral in human body. It plays an important role in the body and is necessary or the synthesis of glutathione, which acts as a potent antioxidant and protect body cells from damaging of certain key proteins. The seeds are normally fermented to make Iru, one of African local supplements in making soup. Sulphur is also believed to help in treating seborrheic dermatitis (a skin conditions) [15-17].

In this work, silicon $(\mathrm{Si})$, a non-toxic element in it natural form when taken into human body has high concentration when compared with Moringa Oleifera the so called "miracle tree" [12]. It reduces hair loss, improving hair and nail quality, improve digestive disorders in human and improve skin healing [18-19]. This work showed that iron (Fe), which has a required concentration in Parkia biglobosa is a mineral that is vital for haemoglobin (a protein required for oxygen in the blood) to function properly. A pregnant woman needs to take food, fruits or vegetables that contain Fe in her dietary because it promotes healthy pregnancy, it also regulates body temperature [20]. 


\section{CONCLUSION}

The results showed clearly that the Parkia biglobosa contains macro, micro and trace elements that are of importance to human health. Extraction from the peal of the stem that is locally used as herbal medicine to treat some ailments should continue. The absence of harmful elements in the plant is a clear indication that the plant will not post any danger when been used as herbal medicine most especially common cold that is not a major problem in Africa. Traditionally, the leave is hardly used for any health purpose and the result showed that it has less concentration of the elements when compared with seed and stem.

\section{REFERENCES}

1. Teklehaimanot Z, (2004); Exploiting the Potential of Indigenous Agroforestry Trees: Parkia Biglobosa and Vitellaria Paradoxa in Sub-Saharan Africa. Agroforestry Systems 61-62(1):207-220 DOI:10.1023/B:AGFO.000002s9000.22293.d1

2. Olowokere, J. A., Onen, A. I., Odineze, M. C., B'aga, I. D., \& Akoji, J. N. (2019). Extraction and Characterization of Oil from African Locust Bean (Parkia biglobosa) Seed. Asian Journal of Applied Chemistry Research, 2(2), 111. https://doi.org/10.9734/ajacr/2018/v2i229677.

3. Agbobatinkpo, Pélagie B., Azokpota, Paulin, Akissoe, Noël, Kayodé, Polycarpe , Da Gbadji, Rachelleand Hounhouigan, D. Joseph(2011) 'Indigenous Perception and Characterization of Yanyanku and Ikpiru: TwoFunctional Additives for the Fermentation of African Locust Bean', Ecology of Food and Nutrition, 50: 2, 101 - 114To link to this Article: DOI: 10.1080/03670244.2011.552369.

4. T.O. Femi-Ola, V.A. Ajibade and A. Afolabi, (2008). Chemical Composition and Termicidal Properties of Parkia biglobosa (Jacq) Benth. Journal of Biological Sciences, 8: 494-497.

5. Omafuvbe, B.O., O.S. Falade, B.A. Osuntogun and S.R.A. Adewusi, 2004. Chemical and biochemical changes in African locust bean (Parkia biglobosa) and melon (Citrullus vulgaris) seeds during fermentation to condiments. Pak. J. Nutr., 3: 140-145.

6. Gernmah D. I. Atolagbe M. O. Echegwo C. C. (2007); Nutritional composition of the African locust bean (Parkia biglobosa) fruit pulp. Nigerian Food Journal Vol. 25 (1) 2007: pp. 190-196

7. Odunfa S.A. (2017); Carbohydrate Changes in Fermentating Locust Bean During I R U Preparation. J. of Plant Foods, pages 105-110| Published online: 27 Sep 2017.

8. Aborisade C. A., Omoniyi A. (2020); Elemental Characterization of Pawpaw (Carica Papaya Linn) From Igbope and Ile-Ife, Southwestern Nigeria Using Particle Induced X-Ray Emission. Int. J. of Sc. \& Tech. Res. 2020;15(3):984-989.

9. Campbell J. L., Ganly C. M, Heirwegh C. M. and Maxwell J. A. (2018); Separation of detector non-linearity issues and multiple ionization satellites in alpha-particle PIXE analysis. Nucl. Instr. Meth. B414, 38-44.

10. Campbell J. L., Heirwegh C. M. and Ganly B. (2016); Non-linearity issues and multiple ionization satellites in the PIXE proton of specta from the Martian alpha particle X-ray spectrometer. Nuclear Instrumentation Methods B383, 143-151.

11. Russell J. L., Campbell J. L., Boyd N. I. and Dias J. F. (2018); GUMAP: a GUPIXWIN-compatible code for extraction regional spectral from nuclear microbeam list mode files. Nuclear Instrumentation and Method. B417 46-50.

12. Aborisade C. A., Ibitoye F. I., Sogeke O. I., Obiajunwa E. I., Balogun F. A. (2019) Essential and Trance Element Content of Moringa Oleifera from Akure and Ile-Ife in the South Wester Nigeria. Ife J. of Sc. 21(1): 235-241.

13. Medically reviewed by Kathy Warwick, R. D. on Jan. 28, 2020 - Written by Tim Newman.

14. Megan Ware, (2018): Everything you need to know about potassium. Medical News Today Published Wed. 10 January 2018.

15. National Health and Nutrition Examination Survey: (2010); Validity of U.S. Nutritional Survellance: National Health and Nutritional Examination Survey Caloric Energy intaie data, 1971-2010.

16. Megan Ware, (2018): Everything you need to know about potassium. Medical News Today Published Wed. 10 January 2018.

17. Tim Newman, (2017); Potassium as important as sodium for healthy blood pressure. Medical News Today Published Saturday, 8 April, 2017.

18. Martin K. R. (2007); The chemistry of silica and its potential health benefits. .J. Nutr. Health Aging. 2007 MarApril; 11(2):94-7.

19. Mehri A. (2020); Trace elements in Human Nutrition (II) - An Update. Int. J. prev. Med. 2020 Jan. 3, 11-12.

20. Medically reviewed by Judith Marcin, M. D. on Feb. 23, 2018 - Written by Megan Ware, RDN, L. D. 